
ISSN : 2615-1995, E-ISSN : 2615-0654

J. Madani., Vol. 3, No. 1, Maret 2020 (42 - 55)

C2018 Lembaga Kajian Demokrasi

dan Pemberdayaan Masyarakat (LKD-PM)

DOI : https://doi.org/10.33753/madani.v3i1.99

\title{
Pengaruh Gaya Kepemimpinan, Pelatihan, dan Kompensasi Terhadap Kinerja Guru Sekolah Al Azhar Bumi Serpong Damai, Tangerang Selatan
}

\author{
Raden Yeti Sumiaty \\ Fakultas Ekonomi, Universitas Pamulang \\ rd.yetisumiaty@gmail.com
}

\begin{abstract}
Abstrak
Penelitian ini bertujuan untuk mengetahui pengaruh gaya kepemimpinan terhadap kinerja guru sekolah AlAzhar BSD Tangerang Selatan-Banten, untuk mengetahui pengaruh pelatihan terhadap kinerja guru sekolah Al-Azhar BSD Tangerang Selatan-Banten, untuk mengetahui pengaruh kompensasi terhadap kinerja guru sekolah Al-Azhar BSD Tangerang Selatan-Banten, dan untuk mengetahui pengaruh gaya kepemimpinan, pelatihan dan kompensasi terhadap kinerja guru sekolah Al-Azhar BSD Tangerang Selatan-Banten. Metode yang gunakan dalam penelitian ini adalah kuantitatifyang bersifat deskriptif analisis. Populasi dalam penelitian ini ialah guru-guru Sekolah Al Azhar BSD yang berjumlah 110 orang dan menggunakan teknik sampel jenuh dimana semua populasi dijadikan sampel dalam penelitian. Hasil penelitian menunjukkan bahwa terdapat pengaruh secara parsial antara gaya kepemimpinan terhadap kinerja guru yang positif sebesar $t_{\text {hitung }} 24,209$ pada taraf signifikansi 0,000. Terdapat pengaruh secara parsial antara pelatihan terhadap kinerja guru yang positif sebesar $t_{\text {hitung }} 19,767$ pada taraf signifikansi 0,000. Terdapat pengaruh secara parsial antara kompensasi terhadap kinerja guru yang positif sebesar $t_{\text {hitung }} 18,667$ pada taraf signifikansi 0,000. Sedangkan hubungan secara simultan terdapat antara gaya kepemimpinan, pelatihan dan kompensasi terhadap kinerja guru yang positif sebesar $f_{\text {hitung }}$ 364,805 dengan taraf signifikansi 0,000. Dapat disimpulkan bahwa hasil penelitian tersebut terdapat pengaruh yang positif dan signifikan baik secara parsial maupun secara simultan sehingga semua hipotesis diterima.
\end{abstract}

Kata Kunci : Gaya Kepemimpinan, Pelatihan, Kompensasi, Kinerja Guru

\begin{abstract}
This study aims to determine the effect of leadership style on the performance of Al-Azhar BSD Tangerang Selatan-Banten school teachers, to determine the effect of training on the performance of Al-Azhar BSD Tangerang Selatan-Banten school teachers, to determine the effect of compensation on the performance of AlAzhar BSD school teachers Tangerang Selatan-Banten, and to find out the influence of leadership style, training and compensation on the performance of Al-Azhar BSD school teachers in South Tangerang-Banten. The method used in this research is quantitative descriptive analysis. The population in this study were the teachers of the Al Azhar BSD School totaling 110 people and used a saturated sample technique in which all populations were sampled in the study. The results showed that there was a partial influence between the leadership style on the positive teacher performance of $t_{\text {count }} 24.209$ at a significance level of 0.000 . There is a partial effect between training on the positive teacher performance of $t_{\text {arithmetic }} 19.767$ at a significance level of 0.000 . There is a partial effect between compensation on the positive teacher performance of $t_{\text {count }} 18.667$ at a significance level of 0.000 . While there is a simultaneous relationship between leadership style, training and compensation to the positive teacher performance of $f_{\text {count }} 364.805$ with a significance level of 0.000. It can be concluded that the results of the study have a positive and significant effect both partially and simultaneously so that all hypotheses are accepted.
\end{abstract}


Keywords: Prinsipal Leadership, Training, Compensation,Performance Teacher

\section{PENDAHULUAN}

Pendidikan Nasional berusaha untuk membimbing warga negara Indonesia kepada pengembangan pribadi yang berdasarkan ketuhanan serta bermasyarakat dan mampu membudayakan alam sekitarnya. Sebagai suatu sistem pendidikan nasional mempunyai tujuan yang jelas, seperti yang telah dijelaskan dalam Undang-undang pendidikan bahwa pendidikan nasional bertujuan untuk mencerdaskan kehidupan bangsa dan untuk mengembangkan manusia seutuhnya yaitu manusia yang beriman dan bertaqwa kepada Tuhan Yang Maha Esa dan berbudi luhur serta memiliki kepribadian yang mantab dan memiliki tanggung jawab yang tinggi kepada masyarakat dan bangsa.

Tidak ada lingkungan bisnis organisasi yang bersifat statis, karena semua pasti akan mengalami perubahan. Perubahan yang diakibatkan oleh keadaan lingkungan yang dinamis dan kompetitif tersebut akan membawa dampak pada perubahan yang lebih besar lagi. Tanpa adanya kompetensi yang didukung oleh sumber daya manusia yang handal, maka organisasi akan mengalami kesulitan untuk dapat bersaing dengan organisasiorganisasi yang lain.

Kinerja guru merupakan salah satu tolak ukur dari kinerja organisasi, sehingga dalam hal ini perlu selalu mengevaluasi prestasi kerja tersebut dalam rangka untuk mempertahankan atau meningkatkan kinerja organisasi dan sebaliknya prestasi kerja yang sudah baik harus dipertahankan atau bahkan selalu ditingkatkan.

Berdasarkan data dikeluarkan oleh Kemendikbud Tahun 2016 menunjukan peningkatan yang positif. Sesusai dengan kinerja guru, dari sebanyak 49 Indikator Kinerja Sasaran Strategis (IKSS) yang mengukur pencapaian sasaran strategis, sebanyak 32 IKSS (65\%) capaian kinerjanya memuaskan, 9 IKSS (18\%) capaian kinerjanya sangat baik, 3 IKSS (6\%) capaian kinerjanya baik, 1 IKSS (2\%) capaian kinerjanya cukup, dan 1 IKSS (2\%) capaian kinerjanya kurang. Sedangkan sebanyak 3 IKSS belum diketahui tingkat capaiannya kinerjanya di tahun 2015 karena hasil baru diperoleh pada tahun 2016, yaitu IKSS persentase guru, pendidik lainnya, dan tenaga kependidikan yang berkinerja baik.

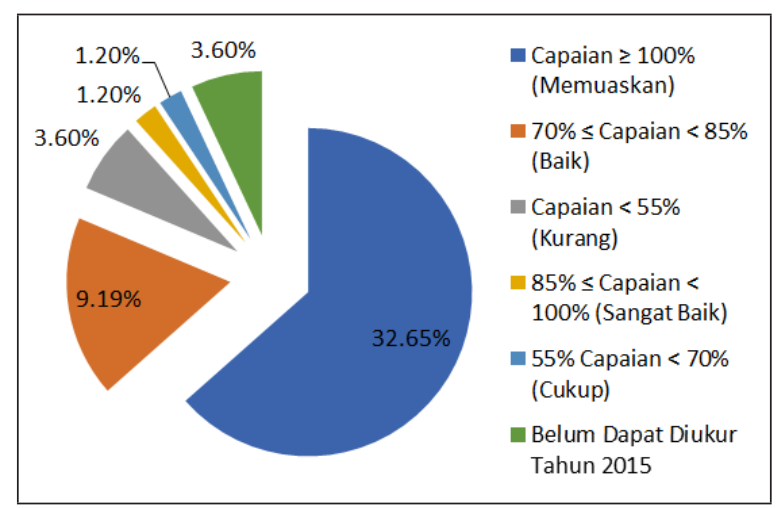

Gambar 1. Rincian Pencapian IKSS

Guru bagi sekolah adalah aset yang paling penting yang harus dimiliki oleh organisasi/ Yayasan dan sangat diperhatikan oleh manajemen. Manusia bermuara dari kenyataan bahwa orang-orang (manusia) merupakan elemen yang senantiasa ada di dalam organisasi. Manusia membuat tujuan, mengadakan inovasi, dan mencapai tujuan organisasi. Sumber daya manusia memicu kreatifitas di setiap organisasi. Tanpa adanya sumber daya manusia yang efektif akan mustahil bagi organisasi untuk mencapai tujuannya.

Banyak faktor yang mempengaruhi kinerja guru, antara lain faktor kepuasan kerja, faktor komunikasi, faktor pengalaman kerja, faktor kedisiplinan, faktor kepemimpinan, faktor kompetensi, faktor kompensasi dan faktor lingkungan kerja. Namun menurut observasi yang dilakukan peneliti berbagai hal permasalahan terebut ditemukan di lokasi penelitian. Sebagian guru menunjukkan disiplin kerja rendah dilihat dari absensi, karyawan datang terlambat, masih adanya karyawan yang pulang lebih cepat, dari observasi dan informasi yang didapatkan dari kepala sekolah masih ditemukan karyawan belum maksimal menuliskan kegiatan kerja, masih adanya karyawan yang menjalankan aktivitas masih rendah, adanya kepemimpinan yang kurang 
tegas, tidak adanya sanksi yang tegas, keluhan karyawan tentang pelatihan yang kurang merata dan kompensasi (gaji) yang belum sesuai, dan hal itu menunjukkan masih rendahnya kinerja sebagian karyawan terhadap organisasi.

Dalam hal ini peneliti ingin mengetengahkan tiga faktor, yaitu faktor kepemimpinan, faktor pelatihan dan faktor kompensasi. Pemilihan ini didasarkan pada kenyataan bahwa ketiga faktor terebut paling sering muncul dalam teori yang membicarakan faktor-faktor yang berpengaruh terhadap kinerja guru.

Komponen-komponen pendidikan tersebut memiliki peran yang penting, salah satu peran penting ada pada guru, karena merupakan ujung tombak dalam proses belajar mengajar. Guru menduduki posisi yang sangat strategis yang akan memberikan konstribusi langsung terhadap kualitas hasil belajar siswa. Dengan demikian jelas bahwa salah satu faktor yang mempengaruhi keberhasilan pendidikan adalah guru. Jika, para guru tersebut menjalankan prinsip-prinsip profesionalisme dalam menjalankan tugas dan fungsinya, akan mengasilkan kinerja yang baik.

Berdasarkan uraian tersebut di atas dapat dikatakan bahwa motivasi adalah sebagai salah satu faktor pendorong prestasi kerja guru, yang harus mendapat perhatian khusus dari pimpinan jika menghendaki kinerja karyawannya meningkat sehingga tujuan yang diharapkan bisa tercapai. Proses memotivasi sangat tergantung pada kemampuan pemimpin dalam mempengaruhi bawahannya dalam upaya untuk mewujudkan tujuan organisasi. Keberhasilan atau kegagalan yang dialami sebagian besar organisasi ditentukan oleh kualitas kepemimpinn yang dimiliki oleh orang-orang yang diserahi tugas memimpin dalam organisasi tersebut.

Pendapat tersebut mencerminkan betapa besar peran kepemimpinan dalam suatu organisasi, sehingga seorang pemimpin diharapkan mempunyai kemampuan memimpin yang dapat dihandalkan agar tujuan organisasi dapat tercapai. Adapun yang dimaksud dengan kemampuan seorang pemimpin adalah kemampuan untuk memotivasi, mempengaruhi, mengarahkan dan berkomunikasi dengan bawahannya. Di samping itu pemimpin juga harus mempunyai perilaku atau cara kepemimpinan yang disesuaikan dengan situasi dan kondisi organisasi, bersifat fleksibel artinya mampu menyesuaikan atau beradaptasi dengan lingkungannya bawahannya. Demikian berpengaruhnya kepemimpinan dalam suatu organisasi sehingga bisa dikatakan bahwa kepemimpinan adalah merupakan faktor penentu berhasil tidaknya suatu organisasi dalam mencapai tujuan organisasi sebagaimana yang diharapkan. Hal ini tercermin kepada kepala sekolah Al Azhar BSD yang masih kurang perhatian kepada guruguru pengajar sehingga penilian kinerja guru masih lemah terhadap komitmen organisasi/sekolah.

Pelatihan merupakan bagian dari pengembangan guru dalam suatu organisasi. Hal ini dikarenakan pelaksanaannya nanti akan menguntungkan individu guru khususnya dan organisasi pada umumnya. Sehingga guru akan mampu melaksanakan tugas-tugasnya yang telah diberikan pimpinannya. Pelatihan dapat meningkatkan kinerja seorang pegawai/guru baik dalam penanganan pekerjaan yang ada saat ini maupun pekerjaan yang ada pada masa yang akan datang sesuai bidang tugas yang diemban dalam organisasi.

Agar kinerja guru meningkat perlu diberikan peluang atau kesempatan dalam mengembangkan segenap potensinya, misalkan dengan cara:

1) Peningkatan pendidikan.

2) Keikutsertaan dalam seminar, pelatihan, lokakarya.

3) Pemberian Kompensasi sebagai imbalan bagi guru berprestasi.

4) Melakukan studi banding dengan sekolahsekolah unggulan.

Melalui kegiatan tersebut diharapkan guruguru dapat meningkatkan kualitas belajarnya dalam pelaksanaan belajar mengajar, termasuk juga kemampuan guru dalam pemanfaatan teknologi informasi sebagai penunjang pembelajaran, hal ini perlu diperhatikan kepada guru-guru $\mathrm{Al}$ Azhar BSD agar mampu bersaing dengan guru-guru dari sekolah unggulan di Tangerang Selatan khususnya dan guru-guru dari sekolah se Indonesia secara umum.

Kompensasi yang diberikan secara benar, 
akan berpengaruh pada para guru lebih terpuaskan dan termotivasi untuk mencapai sasaransasaran organisasi. Semakin baik kompensasi yang diterima oleh guru maka kinerja guru juga semakin baik.

Hal ini dapat merangsang guru-guru untuk terus meningkatkan prestasi dalam mengajar sehingga berdampak kepada peningkatan kinerja dalam mengajar. Pemberian kompensasi selayaknya diberikan atas guru-guru yang memiliki prestasi yang baik dalam mengajar dan membimbing siswanya berdasarkan totalitas dan loyalitas dalam mengajar.

Berdasarkan hal-hal yang telah diuraikan di atas baik fenomena dan data empiris yang penulis sajikan, maka penulis sangat tertarik untuk mengkaji lebih lanjut permasalahan ini dalam bentuk penelitian dan mengambil judul, "Pengaruh Gaya Kepemimpinan, Pelatihan dan Kompensasi Terhadap Kinerja Guru Sekolah AlAzhar Bumi Serpong Damai Tangerang SelatanBanten".

\section{METODE}

\section{Desain Penelitian}

Desain penelitian yang digunakan adalah desain deskriptif analitik kuantitatif yang bertujuan menguraikan sifat dan karakteristik datadata atau variabel yang akan diujikan. Penelitian ini juga menggunakan desain kausal yang bertujuan untuk menganalisa hubungan atau tingkat pengaruh variabel bebas terhadap variael terikat, apakah hubungan cukup signifikan melalui uji regresi. Dalam penelitian ini data yang dipeoleh dianalisis secara statistik menggunakan softwere SPSS 21.

\section{Populasi}

Menurut Sugiyono (2012:80) mengemukakan definisi populasi adalah wilayah generalisasi yang terdiri atas objek atau subjek yang mempunyai kualitas dan karakteristik tertentu yang ditetapkan oleh peneliti untuk dipelajari dan kemudian ditarik kesimpulan.

Populasi adalah semua objek, semua gejala dan semua kejadian atau peristiwa yang akan dipilih harus sesuai dengan masalah yang akan diteliti. Populasi dalam penelitian ini adalah Guru Sekolah Al-Azhar Bumi Serpong Damai Tahun 2016 sejumlah 110 orang.

\section{Sampel}

Adapun pengertian sampel menurut Sugiyono (2011: 81), yaitu sebagian dari jumlah dan karakteristik yang dimiliki oleh populasi tersebut. Teknik pengambilan sampel menggunakan metode jenuh yaitu sejumlah sampel merupakan seluruh poulasi. Adapun sampal penelitian ini sebanyak 110 responden.

\section{Analisis Data dan Uji Hipotesis}

1. Rancangan Analisis
a. Uji Validitas
b. Uji Reliabilitas

2. Uji Asumsi Klasik
a. Uji Normalitas
b. Uji Multikolinearitas
c. Uji Autokoreasi
d. Uji Heteroskedastisi

3. Uji Regresi Linier Sederhana dan Regresi Linier Berganda
a. Uji Regresi Linier Sederhana (Uji Statistik (t))
b. Uji Regresi Linier Berganda (Uji F, serentak/simultan) dengan analisis Analysis of varian (ANOVA)
c. Uji Koefesien Diterminasi

\section{HASIL dan PEMBAHASAN}

\section{Gaya Kepemimpinan}

Irham Fahmi (2013: 15) mengatakan "kepemimpinan adalah suatu ilmu yang mengkaji secara koprehensif tentang bagaimana mengarahkan, mempengaruhi, dan mengawasi orang lain untuk mengerjakan tugas sesuai dengan perintah yang direncanakan".

Gaya kepemimpinan adalah suatu lakon/ peran dalam sistem organisasi tertentu, karenanya seseorang dalam peran formal belum tentu memiliki keterampilan kepemimpinan dan belum tentu mampu memimpin. Istilah kepemimpinan pada dasarnya berhubungan dengan keterampilan, 
kecakapan, dan tingkat pengaruh yang dimiliki seseorang; oleh sebab itu kepemimpinan bisa dimiliki oleh orang yang bukan pemimpin.

\section{Pelatihan}

Pada umumnya setiap organisasi sering terjadi suatu kesenjangan antara kebutuhan akan promosi tenaga kerja yang diharapkan oleh organisasi dengan kemampuan tenaga kerja dalam merespon kebutuhan, organisasi perlu melalukan suatu upaya untuk menjembatani kesenjangan ini. Salah satu cara yang dapat dilakukan organisasi adalah melalui program pelatihan. Melalui program pelatihan diharapkan seluruh potensi yang dimiliki dapat ditingkatkan sesuai dengan keinginan organisasi atau setidaknya mendekati apa yang diharapkan oleh organisasi.

Handoko (2010: 104) menyebutkan bahwa "latihan (training) dimaksudkan untuk memperbaiki penguasaan berbagai keterampilan dan teknik pelaksanaan kerja tertentu, terinci dan rutin".

Menurut Gary Dessler (2009) "pelatihan adalah proses mengajarkan karyawan baru atau yang ada sekarang. Keterampilan dasar yang mereka butuhkan untuk menjalankan pekerjaan mereka. Pelatihan merupakan salah satu usaha dalam meningkatkan mutu sumber daya manusia dalam dunia kerja. Karyawan, baik yang baru ataupun yang sudah bekerja perlu mengikuti pelatihan karena adanya tuntutan pekerjaan yang dapat berubah akibat perubahan lingkungan kerja, strategi, dan lain sebagainya”.

\section{Kompensasi}

Kompensasi merupakan sesuatu yang diterima karyawan sebagai pengganti kontribusi jasa mereka pada perusahaan. Pemberian kompensasi merupakan pelaksanaan fungsi manajemen sumber daya manusia yang berhubungan dengan semua jenis pemberian harga individual. Menurut Sedarmayanti (2010: 239), "kompensasi adalah segala sesuatu yang diterima oleh karyawan sebagai balas jasa kerja mereka".

Menurut Dessler (2007: 46), "kompensasi karyawaan adalah semua bentuk pembayaran atau hadiah yang diberikan kepada karyawan dan muncul dari pekerjaan mereka". Menurut Hasibuan (2012: 118), "kompensasi adalah semua pendapatan yang berbentuk uang, barang langsung atau tidak langsung yang diterima karyawan sebagai imbalan atas jasa yang diberikan kepada perusahaan".

Berdasarkan beberapa definisi di atas, dapat disimpulkan bahwa kompensasi adalah segala sesuatu yang diberikan oleh perusahaan kepada karyawan, sebagai balas jasa atau imbalan atas kinerja yang dihasilkan oleh karyawan, untuk kepentingan perusahaan. Kompensasi bisa berbentuk uang ataupun fasilitas yang diberikan perusahaan pada karyawan.

\section{Kinerja Guru}

Kinerja dapat diartikan sebagai gambaran mengenai tingkat pencapaian pelaksanaan suatu kegiatan atau program atau kebijakan dalam mewujudkan sadaran, tujuan, misi dan visi organisasi yang tertuang dalam rencana strategi suatu organisasi. Beberapa pengertian kinerja yang dikemukakan oleh para penuis:

Menurut Simanjuntak J Payaman (2007: 1), "kinerja adalah tingkat pencapaian hasil atau pelaksanaan tugas tertentu". Menurut Dessler (2007) seperti yang dikutip Mangkuprawira, S (2007). Kinerja merupakan prosedur yang meliputi:

1. Penetapan standar kinerja

2. Penilaian kinerja aktual pegawai dalam hubungan dengan standar-standar ini.

Menurut Vethzal Rivai Ahmad Fawzi (2009), "kinerja adalah hasil atau tingkat keberhasilan seseorang secara keseluruhan selama periode tertentu di dalam melaksanakan tugas dibandingkan dengan berbagai kemungkinan, seperti standar hasil kerja, target atau sasaran atau kriteria yang telah ditentukan terlebih dulu dan telah disepakati bersama".

Menurut Hersey and Blanhard seperti yang dikutip Mangkuprawira, S (2007) "kinerja merupakan suatu fungsi dari motivasi dan kemampuan. Untuk menyelesaikan tugas atau pekerjaan, seseorang harus memiliki derajat kesediaan dan tingkat kemampuan tertentu. Kesediaan dan keterampilan seseorang tidaklah 
cukup efektif untuk mengerjakan sesuatu tanpa pemahaman yang jelas tentang apa yang akan dikerjakan dan bagaimana mengerjakkannya".

Kustriyanto dalam Mangkunegara (2011: 43) juga menyatakan bahwa "kinerja adalah perbandingan hasil yang dicapai dengan peran serta tenaga kerja persatuan waktu”.

Menurut Furtwengler dalam Wibowo (2011: 54) "kinerja dilihat dari hal kecepatan, kualitas, layanan dan nilai maksudnya kecepatan dalam proses kerja yang memiliki kualitas yang terandalkan dan layanan yang baik dan memiliki nilai merupakan hal yang dilihat dari tercapainya kinerja atau tidak".

Selanjutnya M. Yani (2012: 117) menyatakan bahwa "penilaian kinerja didasarkan pada pemahaman, pengetahuan, keahlian, kepiawaian dan perilaku yang diperlukan untuk melaksanakan suatu pekerjaan dengan baik dan analisis tentang atribut perilaku seseorang sesuai kriteria yang ditentukan untuk masing-masing pekerjaan".

Menurut Costello dalam Wibowo (2011: 11) bahwa "kinerja adalah gambaran mengenai tingkat pencapaian pelaksanaan suatu kegiatan/ program, kebijakan dalam mewujudkan sasaran, tujuan, visi dan misi organisasi yang tertuang dalam strategic planning suatu organisasi”.

Sedangkan menurut Bacal dalam Wibowo (2011: 8) juga menyatakan bahwa "pengukuran kinerja adalah suatu proses penilaian kemajuan pekerjaan terhadap tujuan dan sasaran yang telah ditentukan sebelumnya termasuk informasi atas efisiensi penggunaan sumber daya dalam menghasilkan barang/jasa, hasil kegiatan dibandingkan dengan maksud yang diinginkan".

Kinerja karyawan dipengaruhi oleh sejumlah faktor antara lain: Menurut Sutermeister dalam Hasibuan (2009: 54) terdiri dari motivasi, kemampuan, pengetahuan, keahlian, pendidikan, pengalaman, pelatihan, minat, sikap kepribadian kondisi-kondisi fisik dan kebutuhan fisiologis, kebutuhan social dan kebutuhan egoistik.

Sedangkan menurut Wibowo (2012:14) ada beberapa elemen pokok yaitu:

1) Menetapkan tujuan, sasaran, dan strategi organisasi.

2) Merumuskan indikator dan ukuran kinerja.
3) Mengukur tingkat ketercapaian tujuan dan sasaran-sasaran organisasi.

4) Evaluasi kinerja (feedback)

Hasil

\section{Uji Validitas}

Hasil uji validitas dilakukan dengan menggunakan korelasi Pearson Product Moment. Dalam uji validitas ini, kriteria suatu nilai dapat dinyatakan valid jika nilai tersebut lebih besar dari $\mathrm{r}_{\text {tabel }}\left(\mathrm{r}_{\text {hitung }}>\mathrm{r}_{\text {tabel }}\right)$. Dimana $\mathrm{r}_{\text {tabel }}$ untuk 110 responden adalah sebesar 0,185.

\begin{tabular}{|c|c|c|c|}
\hline $\begin{array}{c}\text { No. } \\
\text { Pertanyaan }\end{array}$ & $\begin{array}{c}\text { Koefisien Korelasi } \\
\left(r_{\text {hitung }}\right)\end{array}$ & $\begin{array}{l}\text { Distribusi } \\
{\left[\mathbf{r}_{\text {tabel }} \mid\right.}\end{array}$ & Keterangan \\
\hline 1 & 0,799 & 0,185 & Valid \\
\hline 2 & 0,745 & 0,185 & Valid \\
\hline 3 & 0,658 & 0,185 & Valid \\
\hline 4 & 0,859 & 0,185 & Valid \\
\hline 5 & 0,866 & 0,185 & Valid \\
\hline 6 & 0,743 & 0,185 & Valid \\
\hline 7 & 0,382 & 0,185 & Valid \\
\hline 8 & 0,249 & 0,185 & Valid \\
\hline \multicolumn{4}{|r|}{ Sumber: Data diolah } \\
\hline
\end{tabular}

Tabel 2. Uji Validitas Pelatihan ( $\mathrm{X}_{2}$ )

\begin{tabular}{|c|c|c|c|}
\hline $\begin{array}{c}\text { No. } \\
\text { Pertanyaan }\end{array}$ & $\begin{array}{c}\text { Koefisien Korelasi } \\
\left(\mathbf{r}_{\text {hitung }}\right)\end{array}$ & $\begin{array}{c}\text { Distribusi } \\
\left(\mathbf{r}_{\text {tabel }}\right)\end{array}$ & Keterangan \\
\hline 1 & 0,779 & 0,185 & Valid \\
\hline 2 & 0,758 & 0,185 & Valid \\
\hline 3 & 0,760 & 0,185 & Valid \\
\hline 4 & 0,493 & 0,185 & Valid \\
\hline 5 & 0,815 & 0,185 & Valid \\
\hline 6 & 0,764 & 0,185 & Valid \\
\hline 7 & 0,753 & 0,185 & Valid \\
\hline & & \multicolumn{2}{|c}{ Sumber: Data diolah } \\
\hline
\end{tabular}

Tabel 3. Uji Validitas Kompensasi ( $\mathrm{X}_{3}$ )

\begin{tabular}{|c|c|c|c|}
\hline $\begin{array}{c}\text { No. } \\
\text { Pertanyaan }\end{array}$ & $\begin{array}{c}\text { Koefisien Korelasi } \\
\left(\mathbf{r}_{\text {hitung }}\right)\end{array}$ & $\begin{array}{c}\text { Distribusi } \\
\left(\mathbf{r}_{\text {tabel }}\right)\end{array}$ & Keterangan \\
\hline 1 & 0,816 & 0,185 & Valid \\
\hline 2 & 0,737 & 0,185 & Valid \\
\hline 3 & 0,680 & 0,185 & Valid \\
\hline 4 & 0,817 & 0,185 & Valid \\
\hline 5 & 0,533 & 0,185 & Valid \\
\hline 6 & 0,808 & 0,185 & Valid \\
\hline 7 & 0,711 & 0,185 & Valid \\
\hline 8 & 0,800 & 0,185 & Valid \\
\hline 9 & 0,700 & 0,185 & Valid \\
\hline 10 & 0,691 & 0,185 & Valid \\
\hline 11 & 0,699 & 0,185 & Valid \\
\hline 12 & 0,471 & 0,185 & Valid \\
\hline & & & Sumber: Data diolah \\
\hline
\end{tabular}




\begin{tabular}{|c|c|c|c|}
\hline \multicolumn{5}{|c|}{ Tabel 4. Uji Validitas Kinerja Guru (Y) } \\
\hline $\begin{array}{c}\text { No. } \\
\text { Pertanyaan }\end{array}$ & $\begin{array}{c}\text { Koefisien Korelasi } \\
\mathbf{(}_{\text {hitung }} \mathbf{~}\end{array}$ & $\begin{array}{c}\text { Distribusi } \\
\left.\mathbf{( r}_{\text {tabel }}\right)\end{array}$ & Keterangan \\
\hline 1 & 0,825 & 0,185 & Valid \\
\hline 2 & 0,771 & 0,185 & Valid \\
\hline 3 & 0,688 & 0,185 & Valid \\
\hline 4 & 0,777 & 0,185 & Valid \\
\hline 5 & 0,410 & 0,185 & Valid \\
\hline 6 & 0,815 & 0,185 & Valid \\
\hline 7 & 0,744 & 0,185 & Valid \\
\hline 8 & 0,767 & 0,185 & Valid \\
\hline 9 & 0,695 & 0,185 & Valid \\
\hline 10 & 0,708 & 0,185 & Valid \\
\hline 11 & 0,717 & 0,185 & Valid \\
\hline 12 & 0,302 & 0,185 & Valid \\
\hline 13 & 0,740 & 0,185 & Valid \\
\hline 14 & 0,241 & 0,185 & Valid \\
\hline \multicolumn{4}{|l}{} \\
\hline
\end{tabular}

\section{Uji Reliabilitas}

Uji reliabilitas dilakukan untuk melihat konsistensi suatu pengukuran dari suatu varibel. Pengukuran dapat dikatakan reliabel apabila memiliki koefisien Cronbach Alpha lebih dari 0.60. Berikut hasil dari perhitungan reliabilitas dengan menggunakan program SPSS versi 21.0:

\begin{tabular}{|c|l|c|c|}
\hline \multicolumn{5}{c}{ Tabel 5. Hasil Uji Reliabilitas } \\
\hline No. & \multicolumn{1}{|c|}{ Variabel } & $\begin{array}{c}\text { Nilai Cronbach } \\
\text { Alpha }\end{array}$ & Keterangan \\
\hline 1 & Gaya Kepemimpinan $\left(X_{1}\right)$ & 0,824 & Reliable \\
\hline 2 & Pelatihan $\left(\mathrm{X}_{2}\right)$ & 0,859 & Reliable \\
\hline 3 & Kompensasi $\left(\mathrm{X}_{3}\right)$ & 0,908 & Reliable \\
\hline 4 & Kinerja Guru $(Y)$ & 0,902 & Reliabel \\
\hline \multicolumn{4}{|c|}{ Sumber: Data diolah } \\
\hline
\end{tabular}

\section{Uji Normalitas}

Uji Kolmogorov-Smirnov, dimana variable Gaya Kepemimpinan $\left(\mathrm{X}_{1}\right)$, Pelatihan $\left(\mathrm{X}_{2}\right)$ dan Kommpensasi sebagai variabel $\left(\mathrm{X}_{3}\right)$ yang merupakan variabel bebas (independen) terhadap Kinerja Guru sebagai variabel $(\mathrm{Y})$ yang merupakan variabel terikat (dependen), apabila tingkat nilai signifikansi dan nilai K-S Z (Kolmogorov-Smirnov $Z)>0,05$, maka data penelitian berdistribusi tersebut terdistribusi dengan normal.

\section{Tabel 6. Uj̦i Kolmogorov-Smirnov}

One-Sample Kolmogorov-Smirnov Test

\begin{tabular}{|l|l|r|}
\hline \multicolumn{2}{|c|}{ One-Sample Kolmogorov-Smirnov Test } \\
\hline \multirow{2}{*}{$\mathrm{N}$} & & $\begin{array}{c}\text { Unstandardized } \\
\text { Residual }\end{array}$ \\
\hline Normal Parameters ${ }^{\mathrm{a}, \mathrm{b}}$ & & 110 \\
\hline Most Extreme Differences & Mean &, 0000000 \\
\cline { 2 - 3 } & Std. Deviation & 2,53070464 \\
\hline & Absolute &, 064 \\
\cline { 2 - 3 } & Positive &, 064 \\
\cline { 2 - 3 } & Negative &,- 042 \\
\hline Kolmogorov-Smirnov Z & &, 668 \\
\hline Asymp. Sig. (2-tailed) & &, 763 \\
\hline $\begin{array}{l}\text { a. Test distribution is Normal. } \\
\text { b. Calculated from data. }\end{array}$ & \\
\hline
\end{tabular}

\section{Uji Multikolinearitas}

\begin{tabular}{|c|c|c|c|c|c|c|c|c|}
\hline & & Tabc & 7. Uji I & Iultikolin & eritas & & & \\
\hline & & & Coe & ficients $s^{a}$ & & & & \\
\hline & & $\begin{array}{l}\text { Unsta } \\
\text { coe }\end{array}$ & $\begin{array}{l}\text { dardized } \\
\text { cients }\end{array}$ & $\begin{array}{l}\text { Standard- } \\
\text { ized Coef- } \\
\text { ficients }\end{array}$ & $t$ & Siq. & $\begin{array}{r}\text { Collin } \\
\text { Stat }\end{array}$ & $\begin{array}{l}\text { :arity } \\
\text { titcs }\end{array}$ \\
\hline & & B & $\begin{array}{c}\text { Std. } \\
\text { Error }\end{array}$ & Beta & & & $\begin{array}{l}\text { Toler- } \\
\text { ance }\end{array}$ & VIF \\
\hline & (Constant) & .725 & 1,607 & &, 451 & .653 & & \\
\hline 1 & $\begin{array}{l}\text { Gaya } \\
\text { Kepemimpinan }\end{array}$ &, 763 & , 102 & .463 & 7,484 & .000 & ,218 & 4,586 \\
\hline & Pelatihan & .434 & .116 & .227 & 3,725 & , 000 & ,224 & 4,466 \\
\hline & Kompensasi & .370 & .057 & .327 & 6,479 & .000 & .224 & 3,054 \\
\hline
\end{tabular}

Berdasarkan hasil tabel di atas diketahui bahwa, nilai tolerance variabel Gaya Kepemimpinan $\left(\mathrm{X}_{1}\right)$ sebesar 0,218, Pelatihan $\left(\mathrm{X}_{2}\right)$ sebesar 0,224, dan Kompensasi $\left(\mathrm{X}_{3}\right)$ sebesar 0,325 lebih besar dari batas toleransi 0,10 , maka dapat disimpulkan tidak terjadi multikolinieritas $\left(\mathrm{X}_{1}, \mathrm{X}_{2}\right.$, $\left.\mathrm{X}_{3}>0,1\right)$. Sedangkan nilai VIF variabel Gaya Kepemimpinan $\left(\mathrm{X}_{1}\right)$ sebesar 4,586, Pelatihan $\left(\mathrm{X}_{2}\right)$ sebesar 4,466, dan Kompensasi $\left(\mathrm{X}_{3}\right)$ sebesar 3,054 lebih kecil dari batasan VIF 10,00. Sehingga dapat disimpulkan bahwa tidak terjadi multikolinearitas $\left(X_{1}, X_{2}, X_{3}<10,00\right)$.

\section{Uji Autokoreasi}

\begin{tabular}{|c|c|c|c|c|c|}
\hline \multicolumn{7}{|c|}{ Tabel 8. Hasil Uji Autokorelasi } \\
\hline Model & $\mathbf{R}$ & R Square & $\begin{array}{c}\text { Adjusted } \\
\text { R Square }\end{array}$ & $\begin{array}{c}\text { Std. Error } \\
\text { of the } \\
\text { Estimate }\end{array}$ & $\begin{array}{c}\text { Durbin- } \\
\text { Watson }\end{array}$ \\
\hline 1 &, $955 a$ &, 912 &, 909 & 2,566 & 1,743 \\
\hline a. Predictors: (Constant), Kompensasi, Pelatihan, Gaya Kepemimpinan \\
\hline \multicolumn{4}{|l}{ b. Dependent Variable: Kinerja Guru } \\
\hline
\end{tabular}


Berdasarkan hasil tabel di atas, diketahui bahwa nilai DW, 1,743 dan hasil tersebut berada diantara tabel DW test $(1,55-2,46)$, sesuai dengan ketentuan pada pedoman Durbin-Watson test model regresi ini tidak terjadi Autokorelasi.

\section{Uji Heteroskedastisi}

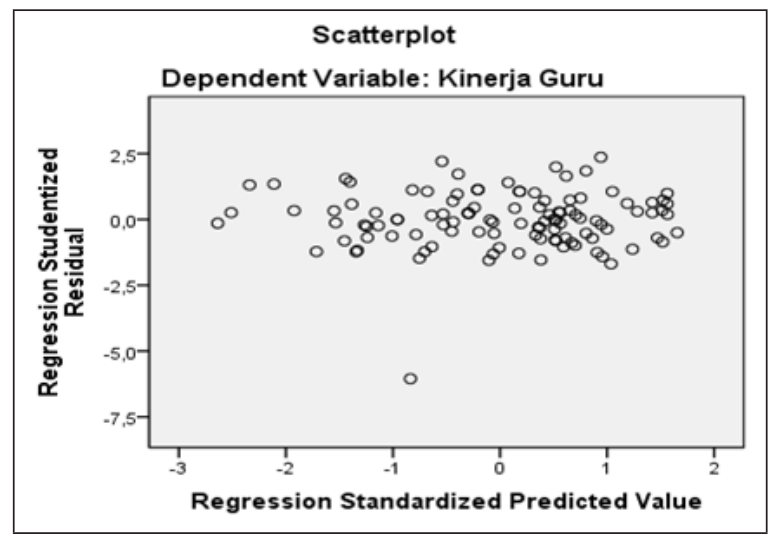

Gambar 2. Uji Heteroskedastisitas

Dari tabel di atas bahwa variance variable Gaya Kepemimpinan $\left(\mathrm{X}_{1}\right)$, Pelatihan $\left(\mathrm{X}_{2}\right)$, dan Kompensasi $\left(\mathrm{X}_{3}\right)$ terhadap Kinerja Guru (Y) tidak sama untuk semua pengamatan atau observasi. Pendistribusian penyebaran titik-titik data tidak teratur dan tidak membentuk pola tertentu, serta tersebar di atas dan dibawah angka 0 (nol) pada sumbu vertikal Y. Jadi dapat disimpulkan bahwa tidak terjadi heteroskedastisitas.

Uji Regresi Linier Sederhana (Uji Statistik (t))

1) Hasil Uji Parsial Gaya Kepemimpinan $\left(X_{1}\right)$ terhadap Kinerja Guru (Y)

Tabel 9. Uji Regresi Sedehana Gaya Kepemimpinan ( $X_{1}$ ) Terhadap Kinerja Guru (Y)

\begin{tabular}{|c|c|c|c|c|c|c|}
\hline \multicolumn{7}{|c|}{ Coefficients $^{\mathrm{a}}$} \\
\hline \multirow{2}{*}{\multicolumn{2}{|c|}{ Model }} & \multicolumn{2}{|c|}{$\begin{array}{l}\text { Unstandardized } \\
\text { Coefficients }\end{array}$} & \multirow{3}{*}{$\begin{array}{c}\begin{array}{c}\text { Standardized } \\
\text { Coefficients }\end{array} \\
\text { Beta }\end{array}$} & \multirow{3}{*}{$\begin{array}{c}t \\
, 298\end{array}$} & \multirow{3}{*}{$\begin{array}{l}\text { Sig. } \\
, 001\end{array}$} \\
\hline & & B & $\begin{array}{l}\text { Std. } \\
\text { Error }\end{array}$ & & & \\
\hline \multirow[b]{2}{*}{1} & (Constant) & 6,409 & 1,943 & & & \\
\hline & $\begin{array}{l}\text { Gaya } \\
\text { Kepemimpinan }\left(X_{1}\right)\end{array}$ & 1,516 &, 063 &, 919 & 24,209 &, 000 \\
\hline \multicolumn{7}{|c|}{ a. Dependent Variable: Kinerja Guru (Y) } \\
\hline
\end{tabular}

Dari tabel di atas didapat nilai $\mathrm{t}_{\text {hitung }} 24,209$ untuk Gaya Kepemimpinan $\left(\mathrm{X}_{1}\right)$ dan nilai $\mathrm{t}_{\text {tabel }}$ adalah 1,659 $(\mathrm{df}=\mathrm{n}-\mathrm{k}, 110-3=107)$. Apabila nilai $\mathrm{t}_{\text {hitung }}>\mathrm{t}_{\text {tabel }}$ maka dapat disimpulkan bahwa terdapat pengaruh yang positif secara parsial, sebaliknya apabila nilai $\mathrm{t}_{\text {hitung }}<\mathrm{t}_{\text {tabel }}$ maka dapat disimpulkan bahwa tidak terdapat pengaruh yang positif. Dari hasil tabel Coefficients di atas dapat disimpulkan bahwa nilai $t_{\text {hitung }}$ Gaya Kepemimpinan $\left(\mathrm{X}_{1}\right)$ 24,209 $>\mathrm{t}_{\text {tabel }} 1,659$, maka dapat disimpulkan terdapat pengaruh yang positif antara variabel Gaya Kepemimpinan $\left(\mathrm{X}_{1}\right)$ secara parsial (sendiri-sendiri) terhadap variabel Kinerja Guru (Y).

Dalam Uji Signifikansi apabila nilai Sig. < dari Signifikansi $\alpha=0,05$, maka dapat disimpulkan bahwa terdapat pengaruh yang Signifikan antara Gaya Kepemimpinan $\left(\mathrm{X}_{1}\right)$ secara parsial terhadap Kinerja Guru (Y), begitu pula sebaliknya apabila nilai Sig $>$ dari Sig $\alpha=0,05$ dapat disimpulkan tidak terdapat pengaruh yang signifikan antara Gaya Kepemimpinan $\left(\mathrm{X}_{1}\right)$ secara parsial terhadap Kinerja Guru (Y).

Dari tabel di atas dapat disimpulkan nilai Sig. Gaya Kepemimpinan $\left(\mathrm{X}_{1}\right)$ sebesar 0,000 < 0,05, maka kesimpulannya terdapat pengaruh yang signifikan antara Gaya Kepemimpinan $\left(\mathrm{X}_{1}\right)$ secara parsial terhadap Kinerja Guru (Y).

Sedangkan model regresi yang diperoleh adalah $\mathrm{y}=6,409+0,919 \mathrm{X}_{1}+\mathrm{e}$. Dengan demikian Constanta sebesar 6,409 menyatakan bahwa tanpa Gaya Kepemimpinan $\left(\mathrm{X}_{1}\right)$, Kinerja Guru (Y) tetap terbentuk sebesar 6,409. Apabila terjadi kenaikan pada variabel Gaya Kepemimpinan $\left(\mathrm{X}_{1}\right)$ sebesar 1, maka akan terjadi kenaikan pada variable Kinerja Guru (Y) sebesar 0, 919.

\section{2) Hasil Uji Parsial Pelatihan $\left(X_{2}\right)$ terhadap Kinerja Guru}

\begin{tabular}{|c|c|c|c|c|c|c|}
\hline \multicolumn{7}{|c|}{$\begin{array}{l}\text { Tabel 10. Uji Regresi Sedehana Pelatihan }\left(X_{2}\right) \\
\text { Terhadap Kinerja Guru (Y) }\end{array}$} \\
\hline \multicolumn{7}{|c|}{ Coefficients $^{\mathrm{a}}$} \\
\hline \multirow{2}{*}{\multicolumn{2}{|c|}{ Model }} & \multicolumn{2}{|c|}{$\begin{array}{l}\text { Unstandardized } \\
\text { Coefficients }\end{array}$} & \multirow{3}{*}{$\begin{array}{c}\begin{array}{c}\text { Standardized } \\
\text { Coefficients }\end{array} \\
\text { Beta }\end{array}$} & \multirow{3}{*}{$\begin{array}{c}t \\
3,192\end{array}$} & \multirow{3}{*}{$\begin{array}{l}\text { Sig. } \\
, 002\end{array}$} \\
\hline & & B & $\begin{array}{l}\text { Std. } \\
\text { Error }\end{array}$ & & & \\
\hline \multirow{2}{*}{1} & (Constant) & 7,428 & 2,327 & & & \\
\hline & Pelatihan ( $\left.\mathrm{X}_{2}\right)$ & 1,690 &, 085 & .885 & 19,767 &, 000 \\
\hline
\end{tabular}

Dari tabel di atas didapat nilai $\mathrm{h}_{\text {hitung }} 19,767$ untuk Pelatihan $\left(\mathrm{X}_{2}\right)$ dan nilai $\mathrm{t}_{\text {tabel }}$ adalah 1,659 $(\mathrm{df}=$ $\mathrm{n}-\mathrm{k}, 110-3=107)$. Apabila nilai $\mathrm{t}_{\text {hitung }}>\mathrm{t}_{\text {tabel }}$ maka dapat disimpulkan bahwa terdapat pengaruh yang 
positif secara parsial, sebaliknya apabila nilai $t_{\text {hitung }}$ $<\mathrm{t}_{\text {tabep }}$ maka dapat disimpulkan bahwa tidak terdapat pengaruh yang positif.

Dari hasil tabel Coefficients di atas dapat disimpulkan bahwa nilai $\mathrm{t}_{\text {hitung }}$ Pelatihan $\left(\mathrm{X}_{2}\right)$ 19,767 $>\mathrm{t}_{\text {tabel }}$ 1,659, maka dapat disimpulkan terdapat pengaruh yang positif antara variabel Pelatihan $\left(\mathrm{X}_{2}\right)$ secara parsial (sendiri-sendiri) terhadap variabel Kinerja Guru (Y).

Dalam Uji Signifikansi apabila nilai Sig. < dari Signifikansi $\alpha=0,05$, maka dapat disimpulkan bahwa terdapat pengaruh yang Signifikan antara Pelatihan $\left(\mathrm{X}_{2}\right)$ secara parsial terhadap Kinerja Guru (Y), begitu pula sebaliknya apabila nilai Sig > dari Sig $\alpha=0,05$ dapat disimpulkan tidak terdapat pengaruh yang signifikan antara Pelatihan $\left(\mathrm{X}_{2}\right)$ secara parsial terhadap Kinerja Guru (Y).

Dari tabel di atas dapat disimpulkan nilai Sig. Pelatihan $\left(\mathrm{X}_{2}\right)$ sebesar $0,000<0,05$, maka kesimpulannya terdapat pengaruh yang signifikan antara Pelatihan $\left(\mathrm{X}_{2}\right)$ secara parsial terhadap Kinerja Guru (Y).

Sedangkan model regresi yang diperoleh adalah y $=7,428+0,885 \mathrm{X}_{1}+$ e. Dengan demikian Constanta sebesar 7,428 menyatakan bahwa tanpa Pelatihan $\left(\mathrm{X}_{2}\right)$, Kinerja Guru (Y) tetap terbentuk sebesar 7,428. Apabila terjadi kenaikan pada variabel Pelatihan $\left(\mathrm{X}_{2}\right)$ sebesar 1 , maka akan terjadi kenaikan pada variable Kinerja Guru (Y) sebesar 0,885 .

\section{3) Hasil Uji Parsial Kompensasi $\left(\mathrm{X}_{3}\right)$ terhadap Kinerja Guru (Y)}

\begin{tabular}{|c|c|c|c|c|c|c|}
\hline \multicolumn{7}{|c|}{$\begin{array}{l}\text { Tabel 11. Uji Regresi Sedehana Kompensasi }\left(X_{3}\right) \\
\text { Terhadap Kinerja Guru (Y) }\end{array}$} \\
\hline \multicolumn{7}{|c|}{ Coefficients $^{\mathrm{a}}$} \\
\hline \multirow{2}{*}{\multicolumn{2}{|c|}{ Model }} & \multicolumn{2}{|c|}{$\begin{array}{l}\text { Unstandardized } \\
\text { Coefficients }\end{array}$} & \multirow{2}{*}{$\begin{array}{c}\begin{array}{c}\text { Standardized } \\
\text { Coefficients }\end{array} \\
\text { Beta }\end{array}$} & \multirow{2}{*}{$t$} & \multirow{2}{*}{ Sig. } \\
\hline & & B & $\begin{array}{l}\text { Std. } \\
\text { Error }\end{array}$ & & & \\
\hline \multirow{2}{*}{1} & (Constant) & 7,147 & 2,478 & & 2,884 &, 005 \\
\hline & Kompensasi $\left(X_{3}\right)$ & .989 &, 053 &, 874 & 18,667 &, 000 \\
\hline
\end{tabular}

Dari tabel di atas didapat nilai $\mathrm{t}_{\text {hitung }} 18,667$ untuk Kompensasi $\left(\mathrm{X}_{3}\right)$ dan nilai $\mathrm{t}_{\text {tabel }}$ adalah $1,659(\mathrm{df}=\mathrm{n}-\mathrm{k}, 110-3=107)$. Apabila nilai $\mathrm{t}_{\text {hitung }}$ $>\mathrm{t}_{\text {tabel }}$ maka dapat disimpulkan bahwa terdapat pengaruh yang positif secara parsial, sebaliknya apabila nilai $\mathrm{t}_{\text {hitung }}<\mathrm{t}_{\text {tabel }}$ maka dapat disimpulkan bahwa tidak terdapat pengaruh yang positif.

Dari hasil tabel Coefficients di atas dapat disimpulkan bahwa nilai $\mathrm{t}_{\text {hitung }}$ Kompensasi $\left(\mathrm{X}_{2}\right)$ $18,667>\mathrm{t}_{\text {tabel }} 1,659$, maka dapat disimpulkan terdapat pengaruh yang positif antara variabel Kompensasi $\left(\mathrm{X}_{3}\right)$ secara parsial (sendiri-sendiri) terhadap variabel Kinerja Guru (Y).

Dalam Uji Signifikansi apabila nilai Sig. < dari Signifikansi $\alpha=0,05$, maka dapat disimpulkan bahwa terdapat pengaruh yang Signifikan antara Kompenasi $\left(\mathrm{X}_{3}\right)$ secara parsial terhadap Kinerja Guru (Y), begitu pula sebaliknya apabila nilai Sig > dari Sig $\alpha=0,05$ dapat disimpulkan tidak terdapat pengaruh yang signifikan antara Kompenasi $\left(\mathrm{X}_{3}\right)$ secara parsial terhadap Kinerja Guru (Y).

Dari tabel di atas dapat disimpulkan nilai Sig. Kompensasi $\left(\mathrm{X}_{3}\right)$ sebesar 0,000 $<0,05$, maka kesimpulannya terdapat pengaruh yang signifikan antara Kompenasi $\left(\mathrm{X}_{3}\right)$ secara parsial terhadap Kinerja Guru (Y).

Sedangkan model regresi yang diperoleh adalah y $=7,147+0,874 \mathrm{X}_{1}+$ e. Dengan demikian Constanta sebesar 7,147 menyatakan bahwa tanpa Kompenasi $\left(\mathrm{X}_{3}\right)$, Kinerja Guru $(\mathrm{Y})$ tetap terbentuk sebesar 7,147. Apabila terjadi kenaikan pada variabel Kompenasi $\left(\mathrm{X}_{3}\right)$ sebesar 1, maka akan terjadi kenaikan pada variable Kinerja Guru (Y) sebesar 0,874 .

Dengan demikian dapat dikatakan bahwa Hipotesis pada penelitian ini setelah di uji secara pasial terhadap semua variabel independen terhadap variabel dependen; $\mathrm{X}_{1}-\mathrm{Y}, \mathrm{X}_{2}-\mathrm{Y}$, dan $\mathrm{X}_{3}-\mathrm{Y}$ Hipotesis diterima (Ha. Positif dan Signifikan).

Uji Regresi Linier Berganda (Uji F, serentak/ simultan) dengan analisis Analysis of varian (ANOVA)

\begin{tabular}{|c|c|c|c|c|c|c|}
\hline \multicolumn{7}{|c|}{ Tabel 12. Uji F (Simulatan) } \\
\hline \multicolumn{7}{|c|}{ ANOVA $^{\mathrm{a}}$} \\
\hline \multicolumn{2}{|c|}{ Model } & $\begin{array}{l}\text { Sum of } \\
\text { Squares }\end{array}$ & Df & $\begin{array}{l}\text { Mean } \\
\text { Square }\end{array}$ & $F$ & Sig. \\
\hline \multirow{3}{*}{1} & Regression & 7207,513 & 3 & 2402,504 & 364,805 &, $000^{\mathrm{a}}$ \\
\hline & Residual & 698,087 & 106 & 6,586 & & \\
\hline & Total & 7905,600 & 109 & & & \\
\hline \multicolumn{7}{|c|}{$\begin{array}{l}\text { a. Predictors: (Constant), Kompensasi }\left(X_{3}\right) \text {, Pelatihan }\left(X_{2}\right) \text {, Gaya Kepemimpinan } \\
\left(X_{1}\right)\end{array}$} \\
\hline \multicolumn{7}{|c|}{ b. Dependent Variable: Kinerja Guru(Y) } \\
\hline
\end{tabular}


Dari tabel di atas didapat nilai $\mathrm{F}_{\text {hitung }} 364,805$ untuk variabel Gaya Kepemimpinan $\left(\mathrm{X}_{1}\right)$, Pelatihan $\left(\mathrm{X}_{2}\right)$ dan Kompensasi $\left(\mathrm{X}_{3}\right)$ dan nilai $\mathrm{f}_{\text {tabel }}$ adalah 2,69 $(\mathrm{df}=\mathrm{n}-\mathrm{k}, 110-3=107)$. Apabila nilai $\mathrm{f}_{\text {hitung }}>\mathrm{f}_{\text {tabel }}$ maka dapat disimpulkan bahwa terdapat pengaruh yang positif secara simultan, sebaliknya apabila nilai $\mathrm{f}_{\text {hitung }}<\mathrm{f}_{\text {tabel }}$ maka dapat disimpulkan bahwa tidak terdapat pengaruh yang positif secara simultan.

Dari hasil tabel ANOVA di atas dapat disimpulkan bahwa nilai $\mathrm{f}_{\text {hitung }}$ sebesar $364,805>\mathrm{f}_{\text {tabel }}$ 2,69, maka dapat disimpulkan terdapat pengaruh yang positif antara variabel Gaya Kepemimpinan $\left(\mathrm{X}_{1}\right)$, Pelatihan $\left(\mathrm{X}_{2}\right)$ dan Kompensasi $\left(\mathrm{X}_{3}\right)$ secara simultan (bersama-sama) terhadap variabel Kinerja Guru (Y Dalam Uji Signifikansi apabila nilai Sig. $<$ dari Signifikansi $\alpha=0,05$, maka dapat disimpulkan bahwa terdapat pengaruh yang Signifikan antara Gaya Kepemimpinan $\left(\mathrm{X}_{1}\right)$, Pelatihan $\left(\mathrm{X}_{2}\right)$ dan Kompensasi $\left(\mathrm{X}_{3}\right)$ secara simultan terhadap Kinerja Guru (Y), begitu pula sebaliknya apabila nilai Sig $>$ dari Sig $\alpha=0,05$ dapat disimpulkan tidak terdapat pengaruh yang signifikan antara Gaya Kepemimpinan $\left(\mathrm{X}_{1}\right)$, Pelatihan $\left(\mathrm{X}_{2}\right)$ dan Kompensasi $\left(\mathrm{X}_{3}\right)$ secara simultan terhadap Kinerja Guru (Y).

Dari tabel di atas dapat disimpulkan nilai Sig. Gaya Kepemimpinan $\left(\mathrm{X}_{1}\right)$, Pelatihan $\left(\mathrm{X}_{2}\right)$ dan Kompensasi $\left(\mathrm{X}_{3}\right)$ sebesar $0,000<0,05$, maka kesimpulannya terdapat pengaruh yang signifikan antara Gaya Kepemimpinan $\left(\mathrm{X}_{1}\right)$, Pelatihan $\left(\mathrm{X}_{2}\right)$ dan Kompensasi $\left(\mathrm{X}_{3}\right)$ secara simultan terhadap Kinerja Guru (Y).

Dengan demikian dapat dikatakan bahwa Hipotesis pada penelitian ini setelah di uji secara simultan terhadap semua variabel independen; $\mathrm{X}_{1}, \mathrm{X}_{2}$ dan $\mathrm{X}_{3}$ terhadap variabel dependen $(\mathrm{Y})$, maka hasilnya Hipotesis diterima (Ha. Positif).

\section{Uji Koefesien Diterminasi}

1) Hasil Pengolahan Data Koefisien Determinasi Secara parsial antara Gaya Kepemimpinan $\left(\mathrm{X}_{1}\right)$ terhadap Kinerja Guru $(\mathrm{Y})$ dengan menggunakan program SPSS versi 21.0, adalah sebagai berikut:

\begin{tabular}{|c|c|c|c|c|}
\hline \multicolumn{7}{|c|}{ Tabel 13. Model Summary } \\
\hline Model & $\mathbf{R}$ & R Square & $\begin{array}{c}\text { Adjusted R } \\
\text { Square }\end{array}$ & $\begin{array}{c}\text { Std. Error of the } \\
\text { Estimate }\end{array}$ \\
\hline 1 & $919^{a}$ &, 844 &, 843 & 3,375 \\
\hline \multicolumn{2}{|l}{ a. Predictors: (Constant), Gaya Kepemimpinan $\left(X_{1}\right)$} \\
\hline
\end{tabular}

Berdasarkan hasil tabel di atas, dapat diperoleh nilai koefisien $\mathrm{R}=0,919$. Artinya korelasi variabel Gaya Kepemimpinan $\left(\mathrm{X}_{1}\right)$ terhadap variabel Kinerja Guru (Y) sebesar 0,919, hal ini dapat di simpulkan bahwa ada hubungan positif secara parsial sebesar 91,9\% antara Gaya Kepemimpinan $\left(\mathrm{X}_{1}\right)$ terhadap Kinerja Guru (Y).

Nilai Koefisien Determinasi R Square $\left(\mathrm{R}^{2}\right)$ sebesar 0,844 , maka dapat disimpulkan bahwa secara parsial Gaya Kepemimpinan $\left(\mathrm{X}_{1}\right)$ berpengaruh terhadap Kinerja Guru (Y) sebesar $84,4 \%$ sedangkan sisanya $15,6 \%$ dipengaruhi oleh faktor-faktor lain yang tidak diteliti dalam penelitian ini.

2) Hasil Pengolahan Data Koefisien Determinasi Secara parsial antara Pelatihan $\left(\mathrm{X}_{2}\right)$ terhadap Kinerja Guru (Y) dengan menggunakan program SPSS versi 21.0, adalah sebagai berikut:

\begin{tabular}{|c|c|c|c|c|}
\hline \multicolumn{5}{|c|}{ Tabel 14. Model Summary } \\
\hline Model & $\mathbf{R}$ & R Square & $\begin{array}{l}\text { Adjusted R } \\
\text { Square }\end{array}$ & $\begin{array}{l}\text { Std. Error of the } \\
\text { Estimate }\end{array}$ \\
\hline 1 &, $885^{\mathrm{a}}$ & .783 &, 781 & 3,981 \\
\hline \multicolumn{5}{|c|}{ a. Predictors: (Constant), Pelatihan $\left(\mathrm{X}_{2}\right)$} \\
\hline
\end{tabular}

Berdasarkan hasil tabel di atas, dapat diperoleh nilai koefisien $\mathrm{R}=0,885$. Artinya korelasi variabel Pelatihan $\left(\mathrm{X}_{2}\right)$ terhadap variabel Kinerja Guru (Y) sebesar 0,885, hal ini dapat di simpulkan bahwa ada hubungan positif secara parsial sebesar $88,5 \%$ antara Pelatihan $\left(\mathrm{X}_{2}\right)$ terhadap Kinerja Guru (Y).

Nilai Koefisien Determinasi R Square $\left(\mathrm{R}^{2}\right)$ sebesar 0,783 , maka dapat disimpulkan bahwa secara parsial Pelatihan $\left(\mathrm{X}_{2}\right)$ berpengaruh terhadap Kinerja Guru (Y) sebesar $78,3 \%$ sedangkan sisanya $21,7 \%$ dipengaruhi oleh faktor-faktor lain yang tidak diteliti dalam penelitian ini.

3) Hasil Pengolahan Data Koefisien Determinasi Secara parsial antara Kompensasi $\left(\mathrm{X}_{3}\right)$ ter- 
hadap Kinerja Guru (Y) dengan menggunakan program SPSS versi 21.0, adalah sebagai berikut:

\begin{tabular}{l}
\hline \multicolumn{5}{|c|}{ Tabel 15. Model Summary } \\
\begin{tabular}{|c|c|c|c|c|}
\hline Model & $\mathbf{R}$ & R Square & $\begin{array}{c}\text { Adjusted R } \\
\text { Square }\end{array}$ & $\begin{array}{c}\text { Std. Error of the } \\
\text { Estimate }\end{array}$ \\
\hline 1 &, $874^{\mathrm{a}}$ &, 763 &, 761 & 4,162 \\
\hline
\end{tabular} \\
\hline
\end{tabular}

Berdasarkan hasil tabel di atas, dapat diperoleh nilai koefisien $\mathrm{R}=0,874$. Artinya korelasi variabel Kompensasi $\left(\mathrm{X}_{3}\right)$ terhadap variabel Kinerja Guru (Y) sebesar 0,874, hal ini dapat di simpulkan bahwa ada hubungan positif secara parsial sebesar $87,4 \%$ antara Kompensasi $\left(\mathrm{X}_{3}\right)$ terhadap Kinerja Guru $(\mathrm{Y})$.

Nilai Koefisien Determinasi R Square $\left(\mathrm{R}^{2}\right)$ sebesar 0,763, maka dapat disimpulkan bahwa secara parsial Kompensasi $\left(\mathrm{X}_{3}\right)$ berpengaruh terhadap Kinerja Guru (Y) sebesar $76,3 \%$ sedangkan sisanya $23,7 \%$ dipengaruhi oleh faktor-faktor lain yang tidak diteliti dalam penelitian ini.

4) Hasil Pengolahan Data Koefisien Determinasi Secara simultan antara Gaya Kepemimpinan $\left(\mathrm{X}_{1}\right)$, Pelatihan $\left(\mathrm{X}_{2}\right)$ dan Kompensasi $\left(\mathrm{X}_{3}\right)$ terhadap Kinerja Guru (Y) dengan menggunakan program SPSS versi 21.0, adalah sebagai berikut:

\begin{tabular}{l}
\hline \multicolumn{7}{|c|}{ Tabel 16. Model Summary } \\
\begin{tabular}{|c|c|c|c|c|}
\hline Model & $\mathbf{R}$ & R Square & $\begin{array}{c}\text { Adjusted R } \\
\text { Square }\end{array}$ & $\begin{array}{c}\text { Std. Error of the } \\
\text { Estimate }\end{array}$ \\
\hline 1 & $.955^{\circ}$ &, 912 &, 909 & 2,566 \\
\hline
\end{tabular} \\
$\begin{array}{l}\left.\text { a. Predictors: (Constant), Kompensasi ( } X_{3}\right) \text {, Pelatihan }\left(X_{2}\right) \text {, Gaya Kepemimpinan } \\
\left(X_{1}\right)\end{array}$ \\
\hline
\end{tabular}

Berdasarkan hasil tabel di atas, dapat diperoleh nilai koefisien $\mathrm{R}=0,955$. Artinya korelasi variabel Gaya Kepemimpinan $\left(\mathrm{X}_{1}\right)$, Pelatihan $\left(\mathrm{X}_{2}\right)$ dan Kompensasi $\left(\mathrm{X}_{3}\right)$ terhadap Kinerja Guru (Y) sebesar 0,955, hal ini dapat di simpulkan bahwa ada hubungan positif secara simultan sebesar 95,5\% antara Gaya Kepemimpinan $\left(\mathrm{X}_{1}\right)$, Pelatihan $\left(\mathrm{X}_{2}\right)$ dan Kompensasi $\left(\mathrm{X}_{3}\right)$ terhadap Kinerja Guru $(\mathrm{Y})$.

Nilai Koefisien Determinasi R Square $\left(\mathrm{R}^{2}\right)$ sebesar 0,912 , maka dapat disimpulkan bahwa secara simultan Gaya Kepemimpinan
$\left(\mathrm{X}_{1}\right)$, Pelatihan $\left(\mathrm{X}_{2}\right)$ dan Kompensasi $\left(\mathrm{X}_{3}\right)$ berpengaruh terhadap Kinerja Guru (Y) sebesar $91,2 \%$ sedangkan sisanya $8,8 \%$ dipengaruhi oleh faktor-faktor lain yang tidak diteliti dalam penelitian ini.

\section{Pembahasan}

Berdasarkan dari hasil pengolahan data statistik yang sudah diteliti, maka dapat diungkapkan pembahasan penelitian antara pengaruh Gaya Kepemimpinan, Pelatihan, dan Kompensasi terhadap Kinerja Guru pada Sekolah Al Azhar Serpong Tangerang Selatan baik secara parsial dan simultan, adalah sebagai berikut:

1. Pengaruh Gaya Kepemimpinan $\left(\mathrm{X}_{1}\right)$ terhadap Kinerja Guru (Y)

Persepsi Gaya Kepemimpinan kepala sekolah dari persepsi responden yang diperoleh melalui angket, menunjukkan bahwa Gaya Kepemimpinan kepala sekolah pada kategori baik. Dari rumusan masalah yang telah diungkapkan pada Bab sebelumnya, bahwa dari hasil uji hipotesis dengan melakukan uji t (uji regresi linier sederhana), ditemukan bahwa terdapat pengaruh yang positif dan signifikan secara parsial antara Gaya Kepemimpinan $\left(\mathrm{X}_{1}\right)$ terhadap Kinerja Guru (Y) pada sekolah Al Azhar Serpong Tangsel. Hal ini dibuktikan dengan hasil uji t dengan menggunakan bantuan program SPSS versi 21.0, dimana $t_{\text {hitung }}$ sebesar 24,209 lebih besar dari $\mathrm{t}_{\text {tabel }} 1,659(24,209>1,659)$ dengan tingkat probabilitas (a sig) sebesar 0,000 lebih kecil dari $\alpha=0,05(0,000<0,05)$, sehingga untuk hipotesis pertama diterima (Ha1 diterima).

Hal ini juga didukung oleh peneliti sebelumnya oleh, Paeno (2015) dengan judul tesis "Pengaruh Gaya Kepemimpinan dan Motivasi terhadap Kinerja Karyawan", dengan hasil penelitian; Gaya kepemimpinan berpengaruh signifikan terhadap kinerja karyawan sebesar $38,3 \%$, sisanya $61,7 \%$ dipengaruhui oleh faktor lain. Motivasi berpengaruh secara signifikan terhadap kinerja karyawan sebesar 32,2\%dan sisanya $67,8 \%$ dipengaruhi oleh faktor lain. Gaya kepe- 
mimpinan dan motivasi secara bersama-sama berpengaruh positif terhadap kinerja karyawan sebesar $45,1 \%$ dan selebihnya $54,9 \%$ dipengarui oleh variabel lain diluar penelitian ini. $\mathrm{F}_{\text {hitung }}>\mathrm{F}_{\text {tabel }} 44,392>3,08$ dengan nilai signifikan $0,000<0,005$, sehingga Ho ditolak dan Ha diterima.

2. Pengaruh Pelatihan $\left(\mathrm{X}_{2}\right)$ terhadap Kinerja Guru (Y)

Berdasarkan hasil olah data statistik atas jawaban responden, ditemukan bahwa persepsi variabel Pelatihan $\left(\mathrm{X}_{2}\right)$ pada sekolah $\mathrm{Al}$ Azhar Serpong Tangsel pada katagori baik. Hipotesis kedua yang diajukan oleh penulis bahwa terdapat pengaruh yang positif dan signifikan secara parsial antara Pelatihan $\left(\mathrm{X}_{2}\right)$ terhadap Kinerja Guru (Y) diterima, hal ini dibuktikan dengan melakukan uji $\mathrm{t}$ dengan menggunakan program SPSS versi 21.0, dengan hasil sebagai berikut, dimana $\mathrm{t}_{\text {hitung }}$ sebesar 19,767 lebih besar dari $\mathrm{t}_{\text {tabel }} 1,659$ $(19,767>1,659)$ dengan tingkat probabilitas ( $\alpha$ sig) sebesar 0,000 lebih kecil dari $\alpha=0,05$ $(0,000<0,05)$, sehingga untuk hipotesis kedua diterima (Ha2 diterima).

Hal ini juga sejalan dengan peneliti sebelumnya oleh, Khairul Akhir Lubis (2008), dengan judul tesis "Pengaruh Pelatihan dan Motivasi kerja terhadap kinerja karyawan PT. Perkebunan Nusantara IV (Persero), Medan". Dengan hasil penelitian; Adanya pengaruh yang signifikan baik secara parsial dan simultan antara pelatihan $\left(\mathrm{X}_{1}\right)$, motivasi kerja $\left(\mathrm{X}_{2}\right)$ terhadap kinerja karyawan $(\mathrm{Y})$, dengan nilai $\mathrm{R}^{2}$ diperoleh sebesar 8,81\% hal ini menunjukan kemampuan variabel independen (pelatihan dan motivasi) menjelaskan pengaruhnya terhadap variabel dependen (kinerja karyawan) sebesar $8,81 \%$, sedangkan sisanya merupakan variabel yang tidak terungkap.

3. Pengaruh Kompensasi $\left(\mathrm{X}_{3}\right)$ terhadap Kinerja Guru (Y)

Berdasarkan hasil olah data statistik atas jawaban responden, ditemukan bahwa persepsi variabel Kompensasi $\left(\mathrm{X}_{3}\right)$ pada sekolah Al Azhar Serpong Tangsel pada katagori baik.
Hipotesis ketiga yang diajukan oleh penulis bahwa terdapat pengaruh yang positif dan signifikan secara parsial antara Kompensasi $\left(\mathrm{X}_{3}\right)$ terhadap Kinerja Guru (Y) diterima, hal ini dibuktikan dengan melakukan uji $\mathrm{t}$ dengan menggunakan program SPSS versi 21.0, dengan hasil sebagai berikut, dimana $\mathrm{t}_{\text {hitung }}$ sebesar 18,667 lebih besar dari $\mathrm{t}_{\text {tabel }} 1,659$ $(18,667>1,659)$ dengan tingkat probabilitas ( $\alpha$ sig) sebesar 0,000 lebih kecil dari $\alpha=0,05$ $(0,000<0,05)$, sehingga untuk hipotesis ketiga diterima (Ha3 diterima).

Hal ini juga sejalan dengan peneliti sebelumnya oleh Siti Rohimah (2013), dengan judul tesis "Pengaruh Kompetensi, Kompensasi, Disiplin Kerja terhadap Kinerja dan Kepuasan Kerja Guru SMA Islamic Village Karawaci, Tangerang”. Dengan hasil penelitian; Terdapat pengaruh yang signifikan, hal dapat dilihat dari kolom Betta, bahwa pengaruh terbesar adalah variabel disiplin kerja sebesar 0,377. Hasil pengolahan data dari tabel uji regresi linier berganda didapat variabel disiplin kerja $\left(\mathrm{X}_{2}\right)$ memiliki nilai yang signifikan 0,017 lebih kecil dari nilai a sebesar 0,05, maka variabel disiplin kerja berpengaruh signifikan terhadap kinerja guru.

4. Pengaruh Gaya Kepemimpinan $\left(\mathrm{X}_{1}\right)$, Pelatihan $\left(\mathrm{X}_{2}\right)$ dan Kompensasi $\left(\mathrm{X}_{3}\right)$ secara simultan terhadap variabel dependen Kinerja Guru (Y)

Berdasarkan hasil olah data statistik di atas dengan menggunakan program SPSS versi 21.0, akan menjelaskan pengaruh Gaya Kepemimpinan $\left(\mathrm{X}_{1}\right)$, Pelatihan $\left(\mathrm{X}_{2}\right)$ dan Kompensasi $\left(\mathrm{X}_{3}\right)$ secara simultan terhadap Kinerja Guru (Y). Dari tabel di atas Nilai $\mathrm{F}_{\text {hitung }}$ dalam tabel ANOVA sebesar 364,805 sedangkan $\mathrm{F}_{\text {tabel }}$ sebesar 2,69, maka data tersebut dapat dikatakan terjadi pengaruh simultan yaitu $\mathrm{F}_{\text {hitung }}$ lebih besar dari $\mathrm{F}_{\text {tabel }}$ $(364,805>2,69)$ sehingga berpengaruh positif. Apabila dihitung dari nilai signifikasi menghasilkan nilai sig. $0,000<\alpha=0,05$, maka hasil yang di dapat berpengaruh secara signifikan, sehingga untuk hipotesis keempat diterima (Ha4 diterima). 


\section{SIMPULAN}

Berdasarkanhasilpenelitian dan pembahasan, maka dapat ditarik kesimpulan sebagai berikut: ada pengaruh positif dan signifikan secara parsial antara Gaya Kepemimpinan $\left(\mathrm{X}_{1}\right)$ terhadap Kinerja Guru (Y) di Sekolah Al Azhar Serpong, Tangerang Selatan. Hal ini ditunjukkan oleh nilai $\mathrm{t}_{\text {hitung }}>\mathrm{t}_{\text {tabel }}$ $(24,209>1,659)$, dengan nilai signifikansi sebesar $0,00<\alpha=0,05$, maka Hipotesis (Ha diterima). Nilai Koefisien Determinasi R Square $\left(\mathrm{R}^{2}\right)$ sebesar 0,844, maka dapat disimpulkan bahwa secara parsial Gaya Kepemimpinan $\left(\mathrm{X}_{1}\right)$ berpengaruh terhadap Kinerja Guru (Y) sebesar 84,4\% sedangkan sisanya $15,6 \%$ dipengaruhi oleh faktor-faktor lain yang tidak diteliti dalam penelitian ini; ada pengaruh positif dan signifikan secara parsial antara Pelatihan $\left(\mathrm{X}_{2}\right)$ terhadap Kinerja Guru $(\mathrm{Y})$ di Sekolah Al Azhar Serpong, Tangerang Selatan. Hal ini ditunjukkan oleh nilai $t_{\text {hitung }}>t_{\text {tabel }}(19,767$ $>1,659)$, dengan nilai signifikansi sebesar 0,00 $<\alpha=0,05$, maka Hipotesis (Ha diterima). Nilai Koefisien Determinasi $\mathrm{R}$ Square $\left(\mathrm{R}^{2}\right)$ sebesar 0,783, maka dapat disimpulkan bahwa secara parsial Pelatihan $\left(\mathrm{X}_{2}\right)$ berpengaruh terhadap Kinerja Guru (Y) sebesar 78,3\% sedangkan sisanya $21,7 \%$ dipengaruhi oleh faktor-faktor lain yang tidak diteliti dalam penelitian ini' ada pengaruh positif dan signifikan secara parsial antara Kompensasi $\left(\mathrm{X}_{3}\right)$ terhadap Kinerja Guru (Y) di Sekolah Al Azhar Serpong, Tangerang Selatan. Hal ini ditunjukkan oleh nilai $\mathrm{t}_{\text {hitung }}>\mathrm{t}_{\text {tabel }}(18,667$ $>1,659)$, dengan nilai signifikansi sebesar 0,00 $<\alpha=0,05$, maka Hipotesis (Ha diterima). Nilai Koefisien Determinasi R Square $\left(\mathrm{R}^{2}\right)$ sebesar 0,763, maka dapat disimpulkan bahwa secara parsial Kompensasi $\left(\mathrm{X}_{3}\right)$ berpengaruh terhadap Kinerja Guru (Y) sebesar 76,3\% sedangkan sisanya $23,7 \%$ dipengaruhi oleh faktor-faktor lain yang tidak diteliti dalam penelitian ini' ada pengaruh positif dan signifikan secara simultan antara Gaya Kepemimpinan $\left(\mathrm{X}_{1}\right)$, Pelatihan $\left(\mathrm{X}_{2}\right)$ dan Kompensasi $\left(\mathrm{X}_{3}\right)$ terhadap Kinerja Guru (Y) di Sekolah Al Azhar Serpong, Tangerang Selatan. Hal ini ditunjukkan oleh nilai $\mathrm{f}_{\text {hitung }} 364,805>$ $\mathrm{f}_{\text {tabel }} 2,69$, dengan nilai signifikansi sebesar 0,00 $<\alpha=0,05$, maka Hipotesis (Ha diterima). Nilai Koefisien Determinasi R Square $\left(\mathrm{R}^{2}\right)$ sebesar
0,912, maka dapat disimpulkan bahwa secara simultan Gaya Kepemimpinan $\left(\mathrm{X}_{1}\right)$, Pelatihan $\left(\mathrm{X}_{2}\right)$ dan Kompensasi (X3) berpengaruh terhadap Kinerja Guru (Y) sebesar 91,2\% sedangkan sisanya $8,8 \%$ dipengaruhi oleh faktor-faktor lain yang tidak diteliti dalam penelitian ini.

\section{PENGHARGAAN}

Pada kesempatan kali ini penulis ingin mengucapkan terimakasih kepada semua yang terlibat baik secara langsung maupun tidak langsung yang tidak bisa penulis sebutkan satu persatu. Terimakasih atas saran, masukan, dan bantuan, semoga penelitian ini bisa bermanfaat bagi semua pihak.

\section{DAFTAR PUSTAKA}

Dessler, G. (2015). Manajemen Sumber Daya Manusia, Edisi 14 (Human Resources Management 14th ed.). Jakarta: Salemba Empat.

Fahmi, I. (2013). Manajemen Kepemimpinan Teori dan Aplikasi. Bandung: Alfabeta.

Khairul Akhir Lubis (2008), dengan judul tesis "Pengaruh Pelatihan dan Motivasi kerja terhadap kinerja karyawan PT. Perkebunan Nusantara IV (Persero), Medan

Hasibuan, M. S. P. (2009). Manajemen Sumber Daya Manusia. Jakarta: Penerbit Bumi Aksara.

Mangkunegara, A. P. (2013). Manajemen Sumber Daya Manusia Perusahaan. Bandung: PT. Remaja Rosdakarya.

Mangkuprawira, S., dan A.V. Hubeis. (2007). Manajemen Mutu Sumber Daya Manusia. Bogor: Ghalia.

Rivai, V. (2009). Manajemen Sumber Daya Manusia Untuk Perusahaan, Cetakan Kedua. Jakarta: PT. Raja Grafindo Persada.

Santoso, S. (2009). Panduan Lengkap Mengenai Statistik dan SPSS 17. Jakarta: Media Komputindo.

Sedarmayanti. (2010). Sumber Daya Manusia dan Produktivitas Kerja. Bandung: CV Mandar Maju.

Simanjuntak, P.J. (2001), Pengantar Ekonomi Sumber Daya Manusia Edisi 2001, Jakarta: 
FE UI.

Sugiyono. (2011). Metode Penelitian Bisnis:

Pendekatan Kuantitatif, Kualitatif, dan R\&D. Bandung: Alfabeta.

Sugiyono. (2012). Metode Penelitian Bisnis: Pendekatan Kuantitatif, Kualitatif, dan R\&D. Bandung: Alfabeta.
Sugiono dan Wibowo. (2002). Statistik Penelitian, Edisi Pertama. Bandung: Alfabeta.

Wibowo, T. (2006). Manajemen Kinerja, Edisi Keempat. Jakarta: Penerbit Rajawali.

Yani, M. (2012). Manajemen Sumber Daya Manusia. Jakarta: Mitra Wacana Media. 